九州大学学術情報リポジトリ

Kyushu University Institutional Repository

\title{
Differentiation of Erwinia chrpsanthemi and $E$. carotovora subsp. carotovora by the Cellular Fatty Acid Analysis
}

Kori, Yuichi

Laboratory of Plant Pathology, Faculty of Agriculture, Kyushu University

Furuya, Naruto

Laboratory of Plant Pathology, Faculty of Agriculture, Kyushu University

Tsuno, Kazunori

Laboratory of Plant Pathology, Faculty of Agriculture, Kyushu University

Matsuyama, Nobuaki

Laboratory of Plant Pathology, Faculty of Agriculture, Kyushu University

https://doi.org/10.5109/24008

出版情報：九州大学大学院農学研究院紀要. 37 (2)，pp.173-178，1992-12. Kyushu University バージョン：

権利関係 : 


\title{
Differentiation of Erwinia chrysanthemi and E. carotovora subsp. carotovora by the Cellular Fatty Acid Analysis
}

\author{
Y uichi K ori, Naruto F uruya, K azunori T suno and N obuaki M atsuyama
}

Laboratory of Plant Pathology, Faculty of Agriculture, Kyushu University 46-01, Fukuoka 812, Japan

(Received July 22, 1992)

\begin{abstract}
For the accurate differentiation of erwinia, the fatty acid analysis of the bacterial cellular membrane of Erwinia species was conducted by gas-liquid chromatography. Striking outcome was obtained in the case of comparison between $E$. chrysanthemi isolates and $E$. carotovora subsp. carotovora. The chromatograms of two Enwinia species were distinctly different. The ratios of the amount of lauric acid (12:0) and myristic acid (14:0) in these two species were reverse each other. In E. chrysanthemi pv. zeae, the fatty acid profile of isolate R7 and R8 from rice was clearly different from that of corn isolate. This result indicates that the fatty acid profile might reflect the differences of the host from which the isolate was obtained. Fatty acids profile will be useful as a benchmark for the classification and identification of phytopathogenic bacteria.
\end{abstract}

\section{INTRODUCTION}

Differentiation of plant pathogenic bacteria has mainly been conducted on the basis of the morphological, physiological and pathological characteristics. In addition to these criteria, the data from serological and chemical analysis of the bacterial cells have been involved, recently (Yaurks and Shaad, 1979). Especially, the analysis of cellular fatty acid composition has been stressed in bacteria such as clavibacter, pseudomonads and some of erwinias (Ikemoto et al., 1978, Suzuki and Komagata, 1983, De Boer and Sasser, 1986).

De Boer and Sasser (1986) analyzed the cellular fatty acids of Emvinia carotovora, the enteric bacterial species, which causes soft rot in many different plants by gas $^{-}$ liquid chromatography. They reported that two subspecies, spp. carotovora and atroseptica, could be differentiated on the basis of three different fatty acid ratios. In previous report, the authors reported that electrophoretic profiles of the outer membranous proteins of Emvinia chrysanthemi isolates were different at pathovar level and sometimes related with hosts from which each isolate was obtained (Uesugi et al., 1990). To examine if the differentiation of pathovars of Emvinia chrysanthemi would also be available by the fatty acid analysis, the following experiments were conducted.

\section{MATERIALS AND METHODS}

\section{B acterial isolates and culture}

Twenty isolates of $\mathbf{E}$. chrysanthemi and 4 isolates of E. carotovora subsp. carotovora maintained in author's laboratory (Table 1) were used in this study. Bacterial isolates were precultured on the plates of YPA medium $(5 \mathrm{~g}$ yeast extract, $10 \mathrm{~g}$ peptone, $5 \mathrm{~g}$ 
$\mathrm{NaCl}, 15 \mathrm{~g}$ agar, dist. water $11, \mathrm{pH} 6.8$ ) at $30^{\circ} \mathrm{C}$ for $24 \mathrm{hr}$ and then cultured in $200 \mathrm{ml}$ of 523 medium (Kado and Heskett, 1970) in Sakaguchi flask by shaking at $30^{\circ} \mathrm{C}$ for $24 \mathrm{hr}$.

\section{Preparation of the samples}

The bacterial cells were harvested by centrifugation $(3,500 \mathrm{Xg}, 30 \mathrm{~min})$, resuspended in $0.85 \% \mathrm{NaCl}$ solution and centrifuged. Five grams (f.wt.) of the precipitated cells were resuspended in $100 \mathrm{ml}$ of $0.2 \mathrm{M} \mathrm{LiCl}$ solution and shaked (156 strokes/min) at 45 " $\mathrm{C}$ for $2.5 \mathrm{hr}$ with $7.5 \mathrm{~g}$ glass beads ( $1 \mathrm{~mm}$ in diameter). The supernatant obtained by centrifugation $(5,000 \times \mathrm{g}, 20 \mathrm{~min})$ was recentrifuged at $30,000 \mathrm{Xg}$ for $40 \mathrm{~min}$ to remove large membranous materials. The resulting supernatant was then centrifuged at $100,000 \mathrm{Xg}$ for $2 \mathrm{hr}$ and the pellet was washed once with distilled water under the same centrifugal condition. All of the centrifugation were conducted at $4{ }^{\circ} \mathrm{C}$. The bacterial outer membrane obtained was lyophilized and stored in a desiccator.

\section{Analysis of fatty acids by G LC}

Five milligrams of the lyophilized outer membrane was methylated with $2 \mathrm{ml}$ of $5 \% \mathrm{HCl}$-methanol at $100^{\circ} \mathrm{C}$ for $3 \mathrm{hr}$. After methanolysis, $1 \mathrm{ml}$ of water was added and

Table 1. Bacterial strains used in this study.

\begin{tabular}{|c|c|c|c|c|}
\hline \multicolumn{3}{|c|}{ Bacterium } & Strain & Isolated from \\
\hline \multicolumn{3}{|c|}{ Erwinia chrysanthemi pv. chrysanthemi } & $\mathrm{Ku} 8601 ”$ & Pear \\
\hline$\eta$ & $n$ & $\eta$ & Ichihara $1-1^{2)}$ & Pear \\
\hline jง & ) & $n$ & E $8301^{3)}$ & Chrysanthemum \\
\hline$n$ & J & pv. zeae & $\mathrm{R} 7^{3)}$ & Rice \\
\hline$n$ & jJ & $\eta$ & $\mathrm{R}^{3)}$ & Rice \\
\hline$n$ & J & Jง & $511-3$ & Corn \\
\hline l) & $n$ & נง & Corn $801^{31}$ & Corn \\
\hline ) & J & נл & Corn $802^{3)}$ & Corn \\
\hline$\eta$ & ") & ") & Corn $803^{3)}$ & Corn \\
\hline Jj & J & נง & ALE $8292 p^{3)}$ & Welsh onion \\
\hline$\eta$ & Jj & נง & NCPPB $377^{5)}$ & Corn \\
\hline$n$ & ) & pv. dian thicola & Dianth $2 n^{3)}$ & Carnation \\
\hline$n$ & 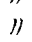 & $n$ & Dianth $1 \mathrm{e}^{3)}$ & Carnation \\
\hline \multicolumn{3}{|c|}{ Erwinia chrysanthemi pv. unidentified } & Ech 33" & Taro \\
\hline$n$ & "I & $n$ & $\operatorname{Ech} 44^{1)}$ & Taro \\
\hline$n$ & 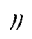 & лง & $342-15^{1)}$ & Onion \\
\hline ") & Jנ & $n$ & $342-16 \mathrm{~S}^{1)}$ & Onion \\
\hline$n$ & ") & נง & $329-21^{1)}$ & Mung bean \\
\hline נง & jง & ") & $329-23^{1)}$ & Mung bean \\
\hline n & $\eta$ & " & E $7188^{41}$ & Potato \\
\hline \multicolumn{3}{|c|}{ Erwinia carotovora subsp. carotovora } & 57 & Chinese cabbage \\
\hline 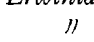 & ju & Jj & B-1 & Brocoli \\
\hline נง & נง & jง & $\mathrm{T}-1$ & Chinese cabbage \\
\hline ") & $n$ & נл & N7101 & Sweet pepper \\
\hline
\end{tabular}

1) Plant Pathology Laboratory, Kyushu University.

2) From Dr. K. Suyama, Tokyo Agricultural University.

3) From Dr. M. Goto, Shizuoka University.

4) From Dr. K. Tsuchiya, National Institute of Agro-Environmental Sciences, Tsukuba, Ibaraki.

5) Purchased from NCPPB. 
fatty acids were extracted with petroleum ether for 3 times. The solvent fraction was washed with the same volume of distilled water to remove $\mathrm{HCl}$, dehydrated with anhydrous $\mathrm{Na}_{2} \mathrm{SO}_{4}$, concentrated by $\mathrm{N}_{2}$ gas blowing and subjected to GLC (Shimazu

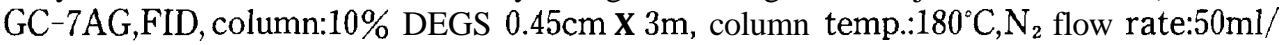
min). Fatty acids were identified by the comparison of retention time(Rt) with the standard. The percentage of each fatty acid was automatically calculated by the integrator (Shimazu C-R1A).

\section{RESULTS AND DISCUSSION}

Ten kinds of fatty acids were detected in the bacterial outer membrane of $E$. chrysanthemi and E.carotovora subsp. carotovora. Lauric acid (12:0), myristic acid (14: 0 ), palmitic acid (16:0), palmitoleic acid (16:1), oleic acid (18:1) and arachidic acid (20: 0 ) were detected in all isolates. Striking difference in the composition of fatty acids was observed between E.carotovora subsp. carotovora strains and $E$. chrysanthemi strains. In the case of $E$. carotovora subsp. carotovora, higher amount of lauric acid and lower amount of myristic acid were characteristically detected and this trend was vice versa in the case of $E$. chrysanthemi isolates (Fig. 1, Table 2). These results showed that E. chrysanthemi and E.carotovora will be differentiated clearly by the fatty acid profile. Especially the ratio of lauric acid and myristic acid will be useful markers. Although such striking difference was not detectable among pathovars of E.chrysanth emi, small but distinct differences were observed between pv. dianthicola and other pathovars. In the case of two isolates of $E$. chrysanthemi pv. dianthicola, higher palmitoleic acid content and no detection of two kinds of unidentified fatty acids (peaks 5,8 in Fig. 1) were characteristically observed.

In pv. zeae, the isolates R7 and R8 from rice were obviously different from the corn isolates. The amounts of unidentified fatty acid (peak 5), arachidic acid and palmitic acid of isolates R7 and R8 were specifically different from those of other isolates. This result might indicate that the fatty acid profile could partly relate with the host from which the isolate was obtained.

Although the similar electrophoretic profiles of cellular membranous protein were obtained among the isolated of pv. zeae (Uesugi et al. 1990), distinct difference was observed in the fatty acid composition.

Among the isolates of unidentified pathovar in $E$. chrysanthemi, the fatty acid profile of isolates 342-15 and 342-16S from onion were similar to the isolate ALE 8298p from Welsh onion, which belongs to pv. zeae. The resemblance was also observed between the isolate E 7188 from potato and two isolates of pv. dianthicola. However, it is uncertain if the isolates $342-15,342-16$ S would be pv. zeae and E 7188 would be pv. dianthicola, respectively.

Although the existence of hydroxy fatty acid (3-OH, 14:0) in E. carotovora pv. carotovora has been reported (De Boer and Sasser, 1986), it was not detected in our experiment. Revision by the different extraction procedures and detection with capillary column at GLC will be required. Some peaks of the unidentified fatty acids such as peak 5,8 and 9 seemed to be the keys of the differentiation. The identification of these substances by the gas chromatography-mass spectrometry (GC-MS) will be requested. 


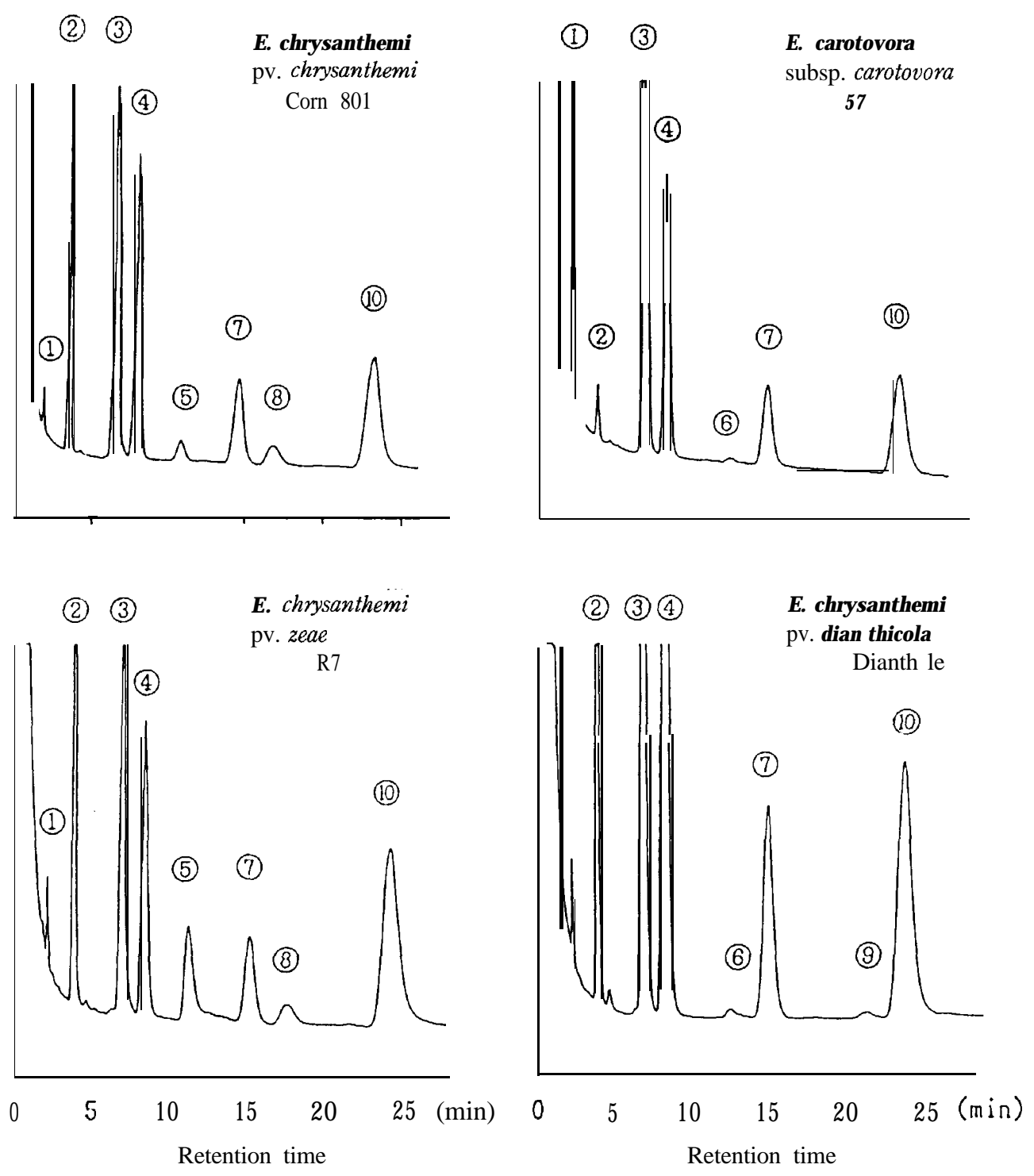

Fig. 1. Gas-liquid chromatograms of fatty acid of bacterial outer membrane in Erwinia chrysanthemi and $E$. carotovora subsp. carotovora. Numbered peaks represent the fatty acids as follows:

(1) Lauric acid (12:0),(2) Myristic acid (14:0),(3) Palmitic acid (16:0),(4) Palmitoleic acid (16:1),(6) Stearic acid (18:0),(7) Oleic acid (18:1),(10) Arachidic acid (20:0),(5),(8),(9) Unknown. 
Table 2. Fatty acid of bacterial outer membrane in Erwinia species.

\begin{tabular}{|c|c|c|c|c|c|c|c|c|c|c|}
\hline \multirow{2}{*}{ Strain } & \multicolumn{10}{|c|}{ Fatty acid ${ }^{1)}$ and Amount } \\
\hline & (1) & (2) & (3) & (4) & (5) & (6) & (7) & (8) & (9) & (10) \\
\hline \multicolumn{11}{|c|}{ E. chrysan themi pv. chrysan themi } \\
\hline $\mathrm{Ku} 8601$ & $0.9^{2)}$ & 17.2 & 293 & 158 & 2.3 & ND & 12.0 & 2.0 & ND & 20.5 \\
\hline Ichihara $1-1$ & 1.4 & 18.2 & 23.0 & 20.1 & 0.9 & ND & 12.6 & 1.1 & ND & 22.6 \\
\hline E 8301 & 0.8 & 14.3 & 25.9 & 29.6 & 0.4 & $\mathrm{ND}$ & 10.8 & ND & ND & 18.2 \\
\hline \multicolumn{11}{|c|}{ E. chrysanthemi pv. zeae } \\
\hline $\mathrm{R} 7$ & 1.2 & 17.4 & 19.4 & 15.6 & 8.8 & ND & 7.8 & 2.4 & ND & 27.2 \\
\hline R8 & 1.3 & 18.3 & 20.1 & 14.8 & 6.6 & ND & 8.5 & 3.0 & ND & 27.2 \\
\hline $511-3$ & 1.3 & 15.1 & 28.8 & 16.4 & 3.0 & 0.6 & 7.8 & 2.3 & ND & 25.1 \\
\hline Corn 801 & 0.9 & 14.2 & 25.6 & 22.3 & 2.1 & ND & 10.6 & 3.5 & ND & 20.7 \\
\hline Corn 802 & 0.9 & 16.5 & 24.8 & 22.1 & 1.5 & ND & 12.4 & 1.5 & ND & 20.4 \\
\hline Corn 803 & 0.9 & 16.6 & 28.3 & 19.0 & 2.2 & ND & 9.8 & 2.4 & ND & 20.8 \\
\hline ALE 8292p & 0.9 & 16.1 & 30.8 & 18.6 & 1.6 & ND & 13.5 & 1.4 & ND & 17.1 \\
\hline NCPPB 377 & 1.8 & 21.0 & 24.4 & 9.5 & 5.4 & ND & 9.2 & 4.4 & ND & 24.3 \\
\hline \multicolumn{11}{|c|}{ E. chrysanthemi pv. diathicola } \\
\hline Dianth 2n & 0.6 & 13.6 & 28.1 & 31.7 & ND & $\mathrm{ND}$ & 7.3 & ND & ND & 18.8 \\
\hline Dianth le & 0.9 & 12.4 & 23.8 & 31.7 & ND & 0.4 & 10.9 & ND & 0.4 & 19.5 \\
\hline \multicolumn{11}{|c|}{ E. chrysanthemi pv. unidentified } \\
\hline Ech 33 & 1.1 & 17.6 & 23.9 & 20.0 & 1.0 & 0.4 & 12.8 & 1.5 & ND & 21.9 \\
\hline Ech 44 & 0.8 & 17.2 & 27.7 & 20.4 & 0.9 & 0.6 & 13.6 & 0.9 & ND & 18.0 \\
\hline $342-15$ & 0.9 & 16.6 & 30.9 & 19.0 & 2.6 & 0.5 & 13.0 & 1.2 & ND & 15.3 \\
\hline $342-16-\mathrm{S}$ & 0.9 & 14.2 & 25.8 & 25.5 & 1.0 & 0.3 & 16.3 & 0.5 & ND & 16.3 \\
\hline $329-21$ & 2.0 & 20.8 & 19.1 & 18.7 & 0.9 & ND & 7.5 & 1.1 & ND & 30.0 \\
\hline $329-23$ & 1.6 & 20.5 & 23.0 & 19.1 & 1.3 & ND & 8.4 & 1.3 & ND & 24.9 \\
\hline E 7188 & 1.0 & 13.0 & 25.3 & 30.7 & 0.5 & 0.7 & 12.7 & 0.4 & ND & 16.1 \\
\hline \multicolumn{11}{|c|}{ E. carotovora subsp. carotovora } \\
\hline 57 & 15.0 & 1.9 & 33.4 & 20.4 & ND & 0.6 & 10.5 & ND & ND & 18.8 \\
\hline B-1 & 14.7 & 3.0 & 31.2 & 18.8 & ND & ND & 10.3 & ND & ND & 22.0 \\
\hline $\mathrm{T}-1$ & 15.2 & 1.5 & 29.0 & 27.2 & ND & ND & 9.0 & ND & ND & 18.0 \\
\hline N 7101 & 14.4 & 1.9 & 37.0 & 19.0 & ND & ND & 11.0 & $\mathrm{ND}$ & ND & 16.7 \\
\hline
\end{tabular}

1) (1)= Lauric acid, (2)= Myristic acid, (3)= Palmitic acid, (4)=Palmitoleic acid

(6) = Stearic acid, (7) = Oleic acid, (10) = Arachidic acid, (5), (8), (9) = unknown

2) Percentage of fatty acid in each strains.

ND: not detected.

Although further work with more isolates would be needed, the results obtained in this experiment will suggest the usefulness of the analysis of fatty acids of bacterial cellular membrane for the identification and classification of bacteria.

\section{ACKNOWLEDGEMENTS}

The authors are grateful to Prof. Dr. S. Wakimoto of Tokyo University of Agriculture (Professor Emeritus of Kyushu University) for his many advices.

\section{REFERENCES}

De Boer, S.H. and H. Sasser 1986 Differentiation of Erwinia carotovora ssp. carotovora and E. 
carotovora ssp. atroseptica on the basis of cellular fatty acid composition. Can. J.Microbiol., 32: 796-800

Ikemoto, S., H. Kuraishi, K. Komagata, R. Azuma, T. Suto and H. Muraoka 1978 Cellular fatty acid composition in Pseudomonas species. J. Gen. Appl.Microbiol., 24: 199-213

Kado, C.I. and M.G. Heskett 1970 Selective media for isolation of Agrobacterium,Corynebacterium, Erwinia, Pseudomonas, and Xanthomonas. Phytopathology, 60: 969-976

Suzuki, K. and K. Komagata 1983 Taxonomic significance of cellular fatty acid composition in some coryneform bacteria. Int. J. Syst. Bacteriol., 33: 188-200

Uesugi, C.H., K. Tsuchiya, K. Tsuno, N. Matsuyama and S. Wakimoto 1990 SDS-polyacrylamide gel electrophoretic profiles of membrane proteins associated with host of origin in Envinia chrysanthemi strains. Ann. Phytopath. Soc. Japan, 56: 597-604

Yaurks, M. and N.W. Shaad 1979 Serological relationships among strains of Enwinia chrysanthemi. Phytopathology, 69: 517-522 